\title{
TAOISM AND MARXISM-LENINISM: HOW TO COMBINE THE OPPOSITES. THE EXPEDIENCY OF SCRUTINIZING THE TRADITIONAL LITERATURE IN THE INVESTIGATION OF MODERN HYBRID WAR
}

\author{
M. Kucheruk \\ $\mathrm{PhD}$ (History), Associate Professor, Assistant Professor \\ Odesa National Polytechnic University \\ 1, Shevchenko avenue, Odesa, 65044, Ukraine \\ kucherukmaryna@ukr.net
}

The author of this article considers the Ancient China military doctrine is extremely functional in managing the hybrid war challenges. There, from antique times exists the subtle art of military craft. That military doctrine had been holding in secret and was recondite even among the Chinese natives. The Western people have to thank the sinologists for the discovering the mysterious Asian word and the translation of the classical works that provides us with the understanding of the Ancient China military doctrine. In the investigation of the hybrid war methods that were applied by V. Lenin the author thinks that it will be appropriate to use the Sun Tzu recommendations. We have no evidence that V. Lenin ever read "The Art of War". It may be seen as a paradox, but in practice, V. Lenin used its recommendations. For instance, "All warfare is based on deception", "Thus, what is of supreme importance in war is to attack the enemy's strategy", etc. The Bolsheviks' policy proves that the capturing of minds was the priority and the specific practical and political steps issued from that. In particular, V. Lenin always started the debates with his opponent from the ideological items. In the opposite, his adversaries were sure that the coverage of ideological issues has no sense. The another character of the Lenin's methodology is its eclecticism. Whem V. Lenin analized Marxism he pointed on the avoiding the dogmatic perception of it and appointed that Marxs, always needed the modification in accordance with the relevant background (see the book "Left-Wing Communism": an Infantile Disorder"). Therefore, nowadays hybrid war has the eclectic essence that combines various forms and means, even non-military. In this sense hybrid war resonates with Zeitgeist - the Globalization that conjoins all the word cultures. Also, the Globalization has made the world visible, and the methods of waging hybrid war are not the new, but revised stratagems old. Court intrigues had left the territory of kings' palaces.

Key words: hybrid war, V. Lenin, Sun Tzu, tao, organization, propaganda, ideology.

ДАОСИЗМ І МАРКСИЗМ-ЛЕНІНІЗМ: ПОЄДНУЮЧИ НЕПОЄДНУВАЛЬНЕ. ЩОДО ДОЦІЛЬНОСТІ ВИВЧЕННЯ КЛАСИКІВ У ДОСЛІДЖЕННІ МЕТОДОЛОГІї ВЕДЕННЯ СУЧАСНОЇ ГІБРИДНОЇ ВІЙНИ

\section{М. С. Кучерук}

До наукового обігу поняття «гібридна війна» запровадив Ф. Гоффман (F.G.Hoffman), відставний офіцерморськоїпіхоти СШАйнауковийспівробітник

C) 2020 M. Kucheruk; Published by the A. Yu. Krymskyi Institute of Oriental Studies, NAS of Ukraine and the Ukrainian Association of Sinologists on behalf of The Chinese Studies. This is an Open Access article distributed under the terms of the Creative Commons Attribution License (https://creativecommons.org/licenses/by-nc-nd/4.0/). 
Національного університету оборони США. Ф. Гоффман указує (що особливо приємно для істориків - як часто нам закидають марність гуманітарних знань в епоху суцільної комп'ютеризації!) на особливу цінність знання історії, особливо «видатного й завжди актуального знавця конфлікту, випадку й людської натури - Фукідіда - актуального як ніколи» [Hoffman]. Говорячи про гібридну війну, фахівець зазначає, що найліпшим терміном для характеристики сучасної війни, що розвивається на наших очах, є «збіжність» (convergence), яка означає поєднання фізичного та психологічного впливів, кінетичної й некінетичної зброї, військових і невійськових, мілітарної сили та спільноти, держави й недержавних акторів [Hoffman].

Гібридні загрози включають весь низку засобів ведення війни включно з традиційними засобами ведення війни, іррегулярними формуваннями, терористичними актами й використанням кримінальних елементів [Hoffman]. Гібридна війна - це явище не нове, проте сама війна змінилася. У цьому виді війни невійськові засоби ведення війн набувають такої ж ваги, як і власне воєнні дії [Hoffman].

Синолог В. Малявін зазначає, що класичні концепції війни склалися в Китаї разом із класичними школами філософської й політичної думки. Це відбулося в епоху, яку традиційно називають епохою Воюючих Царств [Малявин $2016,5]$. Отже, ще задовго до Н. Макіавеллі в Китаї виникла власна військова доктрина. Історія воєн стародавнього Китаю дає нам безліч прикладів ії застосування, багате різноманіття форм і методів (які б зараз назвали гібридними), хитросплетіння інтриг, використання шпигунів, маніпуляцій, інсинуацій тощо. М. Конрад характеризує доктрину Сунь-цзи як учення про загарбницьку війну, що ведеться в інтересах рабовласників (уперше переклад і дослідження, здійснені М. Конрадом, видані в 1950 р.). Разом із тим учений зазначає, що значення трактату Сунь-цзи може бути корисним для розуміння деяких сторін стратегії й тактики країн Дальнього Сходу не тільки в минулому, а й у новий час. Багато положень трактату завжди легко переносилися із царини війни в царину політики й дипломатії [Конрад 2003, 8-9]. М. Конрад зазначає також, що до нього в Російській імперії трактат було видано двічі - Срєзнєвським у 1860 р. у Воєнному збірнику (т. XIII) і Путятою в 1889 р. у Збірці географічних, топографічних і статистичних матеріалів по Азії (т. XXXIX). На Заході вперше Сунь-цзи опубліковано в Лондоні в 1910 р. [Конрад 1977, 21].

На нашу думку, парадоксальною $є$ близькість методів ведення війни, описаних Сунь-цзи і тих, які розробив і застосував В. Ленін. Подібність методології ведення гібридної війни Леніна до Сунь-цзи впадає в очі, але Ленін на нього не посилається. Використовуючи безліч джерел і цитуючи їх, Ленін не застосовує «Мистецтво війни», що й зрозуміло, оскільки ні К. Маркс, ні В. Ленін китайську цивілізацію не вивчали. Проте на практиці В. Ленін застосував усі рекомендації Сунь-цзи: розробив власну теорію, названу потім марксизм-ленінізм («дао»), створив міцну боєздатну партію («армія», «дисципліна»), детально планував кожен свій крок («розрахунки»), повною мірою використовував інтриги для досягнення своїх політичних цілей, розбрат у лавах своїх противників як усередині країни, так і на міжнародній арені («гуманізм», «полководець», «мудрість»), а також уміння враховувати важливість об’єктивної реальності («небо», «земля»).

Методи гібридної війни є універсальними й застосовуваними в будь-яких умовах. Твердження, що не бажано змішувати явища різних культур і використовувати їх надбання обережно, уважаємо недоречним. Фізіологічна 
і психологічна однорідність людства доводить, що за різноманітністю форм уявлень і вчень прихований їх спільний сенс. Одна істина $є$ спільною для всіх культур, від Гебридських островів до Жовтого моря, і навіть головні їх розгалуження виявляються суттєво схожими. Вони несумісні лише на поверхні.

У статті «Три джерела і три складники марксизму» В. Ленін виокремлює тільки те, що вигідно йому: німецьку філософію, англійську політичну економію та французький соціалізм [Ленін 1972, 39-40]. Іще Платон умовно поділив суспільство на три групи: воїнів, ремісників і мудреців. Тільки, на відміну від Платона, який уважав, що суспільством мають керувати філософи, К. Маркс надає перевагу ремісникам. Аристотель обумовив необхідність рабства, його ідею К. Маркс розвиває далі, коли пише про наймане рабство сучасного світу. О. Конт уважав суспільство як функціонуючий організм, усі частини якого органічно пов'язані між собою. I нарешті, монах Т. Кампанелла в книзі «Місто Сонця» писав про ідеальне суспільство, яке пізніше охрестили комунізмом. Те, що Ленін їх не знав, сумнівно, але інформацію подано ним в обрізаному вигляді, що успадкувала система радянської освіти, у якій передбачалося викладання історії, але не всієї, філософії, але лише певних авторів, літератури, тільки такої, де змальований антагонізм класів або ницість верхівки суспільства. Схильність більшовиків до замовчування важливих деталей передалася їхнім політичним спадкоємцям.

Марксизм виник у 1840-х рр. як виразник інтересів робітничого класу Західної Європи. У буремний 1848 рік К. Маркс і Ф. Енгельс створили «Маніфест Комуністичної партії» як програмний документ партії, розробили стратегію і тактику боротьби пролетаріату. Варто зауважити, що марксизм став критичним переосмисленням і творчою переробкою попередньої західноєвропейської думки, адаптованої до сучасних К. Марксу умов і потреб. К. Маркс і Ф. Енгельс узагальнили не тільки досвід класової боротьби трудящих мас, як це подавалося в радянській гуманітарній науці, а й увесь попередній досвід західноєвропейської цивілізації загалом.

Марксизм став закономірним результатом поступального розвитку думки. На нашу думку, найважливішим вкладом К. Маркса у світову скарбницю людської думки є діалектичний матеріалізм - матеріалістичне пояснення світу. Він підійшов до вирішення завдань, які постали перед суспільством XIX століття, і дав наукову відповідь на нагальні питання суспільного розвитку. Марксизм виник у той час, у буремний 1848 рік, коли молодим К. Марксу й Ф. Енгельсу видавалося за просту справу вирішити складні проблеми. У пореволюційній Європі марксисти перетворилися на соціал-демократів. Їх радянська традиція затаврувала, перетворила на опортуністів-ревізіоністів. Ревізіонізм, як прийнято вважати в радянській традиції, виник як «прояв впливу буржуазної ідеології» на нестійких у моральному плані робітників, найменш революційних, забезпечених у матеріальному плані робітників (так звана робітнича аристократія). Іншим джерелом опортунізму радянська традиція вважала ідеологію «дрібнобуржуазних елементів», які вступали до партій пролетаріату [Прохоров 1974, 1158]. Вони були переконані, що краще рухатися в напрямі демократичного узгодження інтересів капіталістів і найманих працівників, ніж знищувати капітал. У їхньому уявленні комунізм мав настати в результаті еволюційного розвитку суспільства, а не революційних, насильницьких, перетворень. В. Ленін пішов іншим шляхом - він підняв революційне вчення марксизму на новий, революційний щабель [Прохоров 1974, 1158]. У радянській традиції В. Леніна охрестили «геніальним продовжувачем справи К. Маркса 
і Ф. Енгельса». С. Кульчицький, навпаки, оцінює більшовиків досить критично: їхня партія не мала за собою соціальних верств, які могли б підтримати іï комуністичну доктрину. Однак В. Ленін замаскував іiі доктринальний екстремізм під стихійний радянський екстремізм [Кульчицький 2008, 8]. Отже, більшовики досягли своєї мети й, застосовуючи різноманітні засоби, із маргіналів перетворилися на правлячу партію.

Книга «Дитяча хвороба «лівизни» в комунізмі написана Леніним до відкриття II конгресу Комуністичного Інтернаціоналу, що проходив улітку 1920 р. Мета іiі написання - допомогти «братнім партіям» віднайти правильний шлях революційної боротьби, фактично, дати рецепт приходу до влади комуністам в інших країнах. У ній Ленін дає власне визначення, як він розуміє диктатуру пролетаріату: це «наполеглива боротьба, кривава й безкровна, насильственна й мирна, воєнна й господарська (імовірно, Ленін мав на увазі економічну боротьбу - aвm.), педагогічна й адміністраторська» [Ленин 1974, 26]. Іншими словами, Ленін учить закордонних «товаришів», як правильно завойовувати владу.

У мистецтві завоювання влади Ленін виділяє три чинники, які необхідно брати до уваги, коли намагаються визначити обставини, що склалися на політичній арені, такі як організація, ідеологія, пропаганда й агітація.

(1) Партійна організація. Перше, на що вказував Ленін у «посібнику», так це дисципліна:

«Повторюю, досвід переможної диктатури пролетаріату в Росії показав наочно тим, хто не вміє думати або кому не доводилося міркувати про иче питання, щзо безумовна ицентралізація і найсуворіма дисиипліна пролетаріату $\epsilon$ однією з основних умов для перемоги над буржуазією» [Ленин 1974, 57].

«Напевно, тепер уже майже кожен бачить, що більшовики не продержалися б при владі не те щз 21/2 роки, а й 21/2 місячі без найсуворішої, справді залізної дисиипліни в намій партії, без найбільш повної й беззавітної підтримки іï всією масою робітничого класу, тобто всім, що є в ньому мислячого, чесного, самовідданого, впливового, здатного вести за собою або захоплювати відсталі верстви» [Ленин 1974, 5].

(2) Ідеологія. Ленін говорив, що спочатку потрібно переконати, а потім уже примусити.

«I насамперед постає питання: чим держиться дисципліна революиійної партії пролетаріату? чим вона перевіряється? По-перше, свідомістю пролетарського авангарду і його відданістю революиії, його витримкою, самопожертвою, героїзмом. По-друге, його вмінням зв'язатися, зблизитися, до певної міри, коли хочете, злитися, з найширшою масою трудящих, передусім пролетарською, але також і непролетарською трудящою масою. По-третє, правильністю політичного керівництва, здійснюваного авангардом, правильністю його політичної стратегї $і$ тактики за умови, щуо найтирші маси власним досвідом переконалися в иіий правильності. Без изих умов дисципліна в революиійній партії, дійсно здатній бути партією передового класу, який має повалити буржуазію і перетворити все суспільство, нездійсненна. Без иих умов спроби створити дисципліну неминуче перетворюються в «пустишку», у фразу, у кривляння. А иі умови, з другого боку, не можуть виникнути відразу. Вони виробляються лише довгою працею, тяжким досвідом; їх вироблення полегшується правильною революиійною теорією, яка, у свою чергу, не є догмою, а остаточно складається лише в тісному зв'язку з практикою дійсно масового, дійсно революиійного руху» [Ленин 1974, 6-7]. 
(3) Пропаганда й агітація. Завдяки своєму «шостому чуттю» В. Леніну вдалося вловити дух нової ери, що настала у XX столітті, - підвищення ролі мас в історії. Якщо раніше політика і війна були справою небагатьох, вузького кола обраних, то з початком Першої світової війни величезна кількість людей була втягнута в політику (що й нині так). Тому третім фактором досягнення успіху більшовиків Ленін позначає пропаганду й агітацію.

«Щоб уміти допомогти «масі» й завоювати симпатії, співчуття, підтримку «маси», треба не боятися труднощів, не боятися причіпок, підніжок, образ, переслідувань з боку "вождів» (які, будучи опортуністами й сочіал-иовіністами, здебільшого прямо або посередньо зв'язані з буржуазією та поліиією) й обов 'язково працювати там, де є маса» [Ленін 1974, 34].

2017 р. у видавництві «Фоліо» вийшла у світ колективна монографія «Світова гібридна війна: український фронт», у якій уперше у вітчизняній і світовій науці детально досліджено явище світової гібридної війни в перспективі російської агресії проти України. Директор Національного інституту стратегічних досліджень В. Горбулін зазначив, що наш досвід не просто заслуговує на пильне вивчення, він єдиний з погляду оцінювання загроз, із яким світові доведеться мати справу найближчим часом, і гібридна війна не почалася й не закінчиться Україною. Вона тільки починається [Горбулін 2016].

У передмові до монографії В. Горбулін стверджує, що людство стоїть перед викликом гібридних війн [Горбулін 2017, 7]. Світ зараз перебуває у вибуховому стані, воєнний конфлікт може спалахнути будь-де, і це об'єктивна реальність. Точкою відліку для формування нового, гібридного світоустрою стала агресія Росії проти України. Авторка статті далека від думки, що наша війна стала причиною виникнення гібридної війни, це радше наслідок процесів глобального масштабу, формування нового, гібридного світоустрою. Військова агресія проти України, що розпочалася у 2014 р., стала найяскравішим прикладом війни сучасності, аж зовсім не причиною виникнення самої гібридної війни. Перед науковцями постало завдання: відреагувати на виклик, описати його не заперечуючи, а приймаючи реальність такою, як вона $є$ [Горбулін 2017, 15-16]. Як сараєвське вбивство вивільнило стиснуту пружину глибоких суперечностей і складних процесів, що призвели до Першої світової війни, так й анексія Криму Росією та іiї дії на Донбасі стали таким самим спусковим гачком для початку нової світової війни, але вже гібридної.

Параметри цієї гібридної війни є відображенням нового гібридного світу: кон'юнктурно надумана причина початку війни, брехня під час іiі розгортання, майже повне моральне розкладання й деградація жителів країни-агресора, при цьому посилені постійним членством у Раді Безпеки ООН дії агресора в рамках формального міжнародного права, створення масованої інформаційної підтримки своїх дій, використання методів «активних заходів» у небачених досі масштабах [Горбулін 2017, 7-8]. В. Горбулін зазначає, що спрощено геополітична мета Росії при розв'язуванні глобального гібридного конфлікту полягає в тому, щоб методами гібридної війни зруйнувати наявний світопорядок, відновити світопорядок часів холодної війни й у ньому посісти звичне місце. Однак проблема полягає в тому, що це буде новий глобальний світо(без)порядок, він не матиме нічого спільного з тим, який прагне повернути Росія. Світо(без)порядок із новою розстановкою країн і новими гібридними війнами, 3 гібридними рішеннями в проблемних ситуаціях і гібридним міжнародним правом. I в цьому вбачається вже загроза для самої Росії [Горбулін 2017, 9]. 
Для перемоги в гібридній війні потрібно активніше й інтенсивніше осмислювати новий підхід і нову реальність, рішуче відмовитися від звичних і типових рішень у всіх сферах - зовнішньополітичній, військовій, економічній, інформаційній. В. Горбулін указує на головний стратегічний виклик: не лише знайти тактично успішні відповіді на гібридну агресію, а й зрозуміти цей новий гібридний світ, зрозуміти його закони й закономірності (які зараз здаються хаосом) і скористатися цими знаннями [Горбулін 2017, 11].

Можна сказати, що сучасна гібридна війна має свого попередника, а саме: війну, яку розв'язали більшовики проти власного народу й проти українців зокрема. Уважаємо, що предмет вивчення гібридної війни сам по собі становить надзвичайно важке завдання, оскільки дослідження методології ведення гібридної війни вимагає застосування міждисциплінарного підходу й інструментарію різних наук, крім власне військової справи: історії, культурології, філософії, психології тощо. На нашу думку, історичний досвід має бути враховано. Зокрема, теоретичні розробки й настанови В. Леніна щодо методів завоювання й утримання влади. Також ми не маємо забувати про витоки гібридної війни, які можна знайти ще раніше. Зокрема, китайська думка та Сунь-цзи.

На постаті Володимира Леніна, точніше, на його методології ведення гібридної війни, і на трактаті «Мистецтво війни» ми зосередимо свою увагу.

Карл фон Клаузевіц - автор книги «Про війну», яка вийшла друком 1832 р. й одразу стала класичною [Клаузевиц]. Він уперше в європейській воєнній науці не тільки дав визначення сутності війни та принципів іiї ведення, а й сформулював стратегічну мету, без досягнення якої будь-які стратегічні дії втрачають сенс. Клаузевіц проаналізував хід наполеонівських воєн і дійшов висновку, що війна в XIX ст. видозмінилася порівняно з попередніми віками: якщо до цього війни були справою лише військового стану й народні маси до них стосунку не мали або майже не мали, то в часи Наполеона та після нього війни набувають національних масштабів, стають по-справжньому народними.

В. Ленін читав К. фон Клаузевіца, імовірно, 1915 р. Вивчення Клаузевіца безпосередньо відображено в літературних роботах Леніна, які відносяться до 1915 р. В. Сорін у газеті «Правда» № 1 за 1923 р. у статті «Марксизм, тактика, Ленін» наводить особисто почуте зауваження В. Леніна, що тактика політична й тактика військова $є$ те, що німецькою називається Grenzgebiet (суміжні галузі), і партійні робітники могли б із користю для себе вивчити роботи К. фон Клаузевіца.

В. Ленін був добре обізнаний із працею К. фон Клаузевіца, навіть використав його військову теорію у власній боротьбі. Ленін не відділяв політику від війни та припускав, що війна може набирати різноманітних форм («війна - це хамелеон»), навіть невійськові засоби Ленін адаптував до воєнних цілей. Уважаємо, використання методів і засобів, які сучасні теоретики характеризують терміном «гібридна війна», i становило перевагу більшовиків над усіма їхніми опонентами. Противники В. Леніна діяли в межах традицій, В. Ленін традиційну війну переступив і пішов далі. Тоді як його опоненти були обмежені рамками традицій, В. Ленін і партія (це не пафос і не іронія, вони дійсно становили одне ціле) не обмежували себе в засобах. Як міфічний Протей, більшовики мімікрували під дійсність і виявляли гнучку тактику, не гребуючи й прямим обманом. Опоненти не змогли зрозуміти В. Леніна - i програли.

У травні 1901 р. В. Ленін написав статтю «3 чого почати?», у якій він виклав конкретний план створення марксистської партії в Росії [Ленин 1984, VII]. В. Ленін підкреслює, що при тогочасних політичних реаліях і поліцейських 
переслідуваннях головною ланкою, з якої потрібно почати створення партії, була загальноросійська політична газети. Вона мала стати не лише колективним пропагандистом та агітатором, а також колективним організатором усіх революційних соціал-демократичних сил у Росії. Це була принципова нова постановка питання про шляхи й методи партійного єднання. Викладений у статті план був практично втілений у життя в діяльності ленінської «Іскри». Усі основні положення статті «3 чого почати?» були згодом детально викладені в праці «Що робити?».

Це парадокс, але деякі твердження В. Леніна суголосні з доктриною Сунь-цзи. В. Ленін:

«Мова йде про систему і план практичної діяльності. I треба визнати, щьо це основне для практичної партії питання про характер і способи боротьби залишається в нас усе ще нерозв'язаним, викликає все ще серйозні незгоди, які виявляють сумну нестійкість і хитання думки. ... Ми могли б, мабуть, висловити, задоволення з приводу того, що «Раб. дело» так швидко засвоїло висунуту нами вже в першому номері «Искры» програму створення міџної організованої партії, спрямованої на завоювання не тільки окремих поступок, а й самої фортеиі самодержавства, але відсутність у тих, що засвоїли, будьякої твердої точки зору може зіпсувати все задоволення. ... Та для того, щоб зміни тактику, треба спершу мати тактику, а коли нема міџної організації, досвідченої в політичній боротьбі при всякій обстановці й у всякі періоди, то не може бути й мови про той систематичний, освітлений твердими принципами та неухильно здійснюваний план діяльності, який тільки й заслуговує назви тактики. ... безпосереднім завданням нашої партії не може бути заклик усіх наявних сил зараз же до атаки, а повинен бути заклик до вироблення революиійної організаиії, здатної об 'єднати всі сили й керувати рухом не тільки за назвою, а й на ділі, тобто бути завжди готовою до підтримки всякого протесту й усякого спалаху, користуючись ними для примноження та змічнення військових сил, придатних для вирімального бою. ... Вимагається не тільки усвідомити, яка саме організація, для якої саме роботи необхідна, вимагається виробити певний план організаиії, щзоб до побудови ії можна було приступити з усіх боків» [Ленин 1969, 5-11].

Сунь-цзи:

«У мистечтвві війни керівними $\epsilon$ n'ять постійних чинників, які беруть до уваги в обговореннях, коли намагаються визначити обставини, шуо склалися на полі.

Це:

(1) Норми моралі;

(2) Небо;

(3) Земля;

(4) Полководеиь;

(5) Метод і дисиипліна.

Через норми моралі люди повністю підтримують свого правителя, тож підуть за ним, пустившись на відчай душі, не злякавшись доброї небезпеки.

Небо означає ніч і день, холод і спеку, часи й сезони.

Земля охоплює відстані, великі й малі; небезпеку й надійність; відкритий простір і вузькі ущелини; можливість вижсити й померти.

Полководець відстоює чесноти мудрості, відвертості, щеедрості, хоробрості та суворості. 
Під «методом і дисиипліною» маємо на увазі керування військом з його устроєм, градацію чинів серед офрічерів, утримування доріг, якими війську можуть доставляти провізію, і контроль за військовими витратами» [Сунь-Цзи 2016, 15-16].

В. Ленін:

«Ця сітка агентів буде кістяком саме такої організаиії, яка нам потрібна: досить великої, щзоб охопити всю краӥну; досить иирокої й рівносторонньої, щзоб провести суворий і детальний поділ праці; досить витриманої, щзоб уміти при всяких обставинах, при всяких «поворотах» $і$ несподіванках вести неухильно свою роботу; досить гнучкої, щзоб уміти, з одного боку, ухилитися від бою у відкритому полі з переважаючим своєю силою ворогом, коли він зібрав на одному пункті всі сили, а з іншого боку, щьоб уміти користуватися неповороткістю иььго ворога й напасти на нього там $і$ тод $i$, де найменше чекають нападу» [Ленин 1969, 11].

Сунь-цзи:

«Варто змінювати плани за доброї оказії.

Усе ведення війни базується на хитрощах.

Тож, коли змога атакувати, маємо прикидатися, щуо не спроможні на цее; коли виконуємо маневр - щоб ані лялечки не видно; коли ми близько, потрібно змусити ворога повірити, що ми далеко; коли ми далеко, потрібно змусити його повірити, щчо ми близько.

Закинь приманку, щоб спокусити ворога. Удай сум'яття $і$ знищ супротивника.

Якще він захищений усіма сторонами, будь готовий до изього. Якщчо він переважає силою, уникай його.

Якще у твого опонента холеричний характер, намагайся роздратувати його. Прикинься слабким, щчоб він став зарозумілим.

Атакуй його, коли він у стані спокою, не давай йому відпочивати. Якщо його сили об'єднані, розділи їх.

Атакуй його там, де він не сподівається тебе побачити, з'явися там, де тебе не чекають» [Сунь-Цзи 2016, 18-19].

В. Ленін:

«Таку міру бойової готовності можна виробити тільки на постійній діяльності, якою займається регулярне військо. Іякщо ми з'єднаємо свої сили на веденні спільної газети, то така робота підготує і висуне не тільки найбільш умілих пропагандистів, а й найбільш вправних організаторів, найталановитіших політичних вождів партії, здатних у потрібну хвилину дати лозунг до вирімального бою і керувати ним» [Ленин 1969, 12].

Сунь-цзи:

«Отже, ми маємо знати п'ять переваг переможия:

(1) переможе той, хто знає, коли ставати до бою, а коли - ні;

(2) переможе той, хто може впоратися й із численнішими, $i$ з меншими військами;

(3) переможе той, чиє військо на всіх чинах надихає одне й те саме;

(4) переможе той, хто, підготувавшись, чекає, щзоб застати ворога непідготовленим;

(5) переможе той, хто має військові здібності й не дає змоги монархові втручатися у свої справи» [Сунь-Цзи 2016, 31].

«Якщо ворог чисельніший, ми можемо уникнути бою. План полягає в тому, щоб викрити його плани та можливість їхнього успіху. 
Розбуди його та вивчи приничипи його дій чи бездіяльності. Змусь його викрити себе, щзоб з'ясувати слабкі місия.

Ретельно порівняй військо опонента зі свойм власним, так ти зможеш дізнатися, де сила переважає, а де ї̈ забракне.

Плануючи тактичні диспозищії, найвища вершина, якої ти можеш досягти, це приховати їх; приховай усі диспозииї, і ти будеш захищений від шпигунських прошуків, від махінацій наймудріших розумів» [Сунь-Цзи 2016, 52-53].

В. Ленін:

«Ми говорили весь час тільки про систематичну, планомірну підготовку, але ми зовсім не хотіли иим сказати, щзо самодержавство може впасти виключно від правильної облоги або організованого штурму. Такий погляд був би безглуздим доктринерством. Навпаки, иілком можливо й історично далеко ймовірніше, щзо самодержавство впаде під тиском одного з тих стихійних вибухів або непередбачених політичних ускладнень, які постійно загрожують $з$ усіх боків. Але ні одна політична партія, не впадаючи в авантюризм, не може будувати своєї діяльності, розраховуючи на такі вибухи й ускладнення. Ми повинні йти своїм шляхом, неухильно робити свою систематичну роботу, $i$, чим менше будемо ми розраховувати на несподіванки, тим більше ймовірності, щзо нас не захоплять зненащька ніякі «історичні повороти» [Ленин 1969, 12].

Сунь-цзи:

«Підбий під свою руку ватажків, завдавши їм збитків; створи для них проблеми й постійно підкидай їм роботу; спокушай їх поспішати до будь-якого заданого місия.

Мистецтво війни вчить нас покладатися не на можливість, щзо ворог не прийде, а на власну готовність прийняти його; не на шанс, щзо він може не атакувати, а радме на те, щзоб зробити свої позичї неприступними» [Сунь-Цзи 2016, 70].

Сунь-цзи:

«Можеш бути впевнений в успішності своїх атак, якщо тільки атакуєш позииї без оборони. Можеш гарантувати надійність своєї оборони, тільки якщо утримуєш позииії, які не можна атакувати.

Тому той генерал майстерний у наступі, чиї опоненти не знають, щьо обороняти, а майстерний він в обороні, якщьо його опоненти не знають, щэо атакувати.

О божсественне мистеитвво хитрощів і вміння тримати все в таємниці! Завдяки тобі ми нечутні; і відтоді доля ворога в наших руках» [Сунь-Цзи 2016, 50].

В. Ленін:

«Коли, пам'ятаючи про иее, ми кинемо загальний погляд на прожиті три роки з погляду міжнародного статусу Радянської республіки, то стане ясно, щзо ми могли продержатися й могли перемогти нечувано могутній союз держав Антанти, підтримуваний нашими білогвардійиями, тільки тому, що ніякої єдності між иими державами не було» [Ленін 1974, 90].

«I, чим глибше, чим грізніше зростатиме комуністичний рух, тим більше повторних спроб зроблять вони для задушення нашої республіки. Звідси наша політика - використати суперечності імперіалістичних держав, щзоб утруднити угоду або по можливості зробити ї̈ тимчасово неможливою» [Ленін 1974, 91].

Сунь-цзи:

«Викривши позиції ворога та залишаючись непоміченими, ми можемо тримати намі сили сконцентрованими, тоді як сили ворога потрібно розділити. 
Ми можемо сформувати єдину об'єднану основну частину, тоді як ворог мусить розділитися на фракиії. Відтоді як нацькуємо їх одна на одну, нас буде багато, а ворога мало.

I якщо ми зможемо атакувати меншу силу більшою, наші опоненти опиняться у скруті» [Сунь-Цзи 2016, 51].

«Якщо військовий командир атакує могутню державу, його майстерне керівництво саме собою виявлясться в тому, щоб не дати ворогу можливості зосередити свої сили. Він уселяє в супротивників страх $і$ не дає змоги своїм союзникам об 'єднатися проти нього» [Сунь-Цзи 2016, 109].

А всю гібридність ленінської війни, на нашу думку, наочно демонструє цитата:

«Кожний погодиться, щзо нерозумна або навіть злочинна поведінка тієї армії, яка не готується оволодіти всіма видами зброї, усіма засобами і прийомами боротьби, які є або можуть бути у ворога. Але до політики щуе ще більше стосується, ніж до військової справи. У політиці щуе менше можна знати наперед, який засіб боротьби буде при тих чи інших майбутніх умовах застосовним $i$ вигідним для нас. Не володіючи всіма засобами боротьби, ми можемо зазнати величезної-іноді навіть вирішальної - поразки, якщо незалежні від намої волі зміни в становищі інших класів висунути на чергу дня таку форму діяльності, у якій ми особливо слабі. Володіючи всіма засобами боротьби, ми перемагаємо напевно, раз ми представляємо інтереси дійсно передового, дійсно революиійного класу, навіть коли обставини не давали нам змоги пустити в хід зброю, найбільш для ворога небезпечну зброю, яка найшвидше завдає смертельних ударів. Неосвічені револючіонери часто думають, щзо легальні засоби боротьби опортуністичні, бо буржуазія на изьому поприщі особливо часто (найпаче в «мирні», не революиійні часи) обманювала й дурила робітників; а нелегальні засоби боротьби революиійні. Але ие неправильно» [Ленін 1974, 76-77].

Вона перегукується із Суни-цзи:

«Вода формує свій курс згідно з природним рельєфом, по якому вона протікає; солдат працює над своє перемогою залежно від ворога, з яким він зіткнеться.

Тому, так само як вода не має постійної форми, і у веденні війни не буває постійних умов.

Того, хто може змінювати свою тактику залежно від свого противни$\kappa а ~ \check{~ т а к ~ д о с я г а є ~ п е р е м о г и, ~ м о ж н а ~ н а з в а т и ~ п р и р о д ж е н и м ~ к о м а н д и р о м » ~}$ [Сунь-Цзи 2016, 55].

Р. Кіплінг колись сказав, що Захід і Схід не зійдуться ніколи. Проте в умовах глобалізації кордони між цивілізаціями, культурами, релігіями, країнами «розмиваються», нації зближуються, навіть змішуються. Так і формується той гібридний світ, про який говорить В. Горбулін. І це одна з ознак гібридності: поєднання того, що здавалось непоєднуваним, зміщення акцентів, мішанина культур і менталітетів. Час заперечив тезу Кіплінга: Захід і Схід сходяться, змішуються й перемішуються. Виникають нові явища, про можливість яких якщо хтось сказав ще сто років тому, його оголосили б божевільним. У наші дні це вже банальність.

Схоже, В. Ленін свій час таки випередив, застосувавши синтетичний підхід. Гібридну війну почали вивчати не більше ніж двадцять років тому, класифікувати сучасні воєнні конфлікти й засоби досягнення воєнних цілей невоєнними методами. А В. Ленін їх усіх застосував, хоча й оголосив своєю метою світову революцію. До Жовтневого перевороту він провів велику організаційну, 
ідеологічну і пропагандистську роботу. Для досягнення цілей військового характеру він застосував усі методи, які могли бути корисними для його мети, у тому числі й невійськові. Можливо, у цьому й полягає сутність сучасної гібридної війни - поєднати (на перший погляд) непоєднувальне.

\section{ЛІТЕРАТУРА}

Горбулін $B$. Гібридна війна: все тільки починається. URL: https://dt.ua/internal/gibridna-viyna-vse-tilki-pochinayetsya-_.html

Горбулін $B$. (Ред.). Світова гібридна війна: український фронт. Харків, 2017.

Клаузевии К. фон. О войне. В 2 т. Москва, Санкт-Петербург, 2002.

Конрад Н. И. Избранные труды: Синология. Москва, 1977.

Конрад Н. И. Трактаты о военном искусстве. Сунь-Цзы, У-Цзы. Москва, Санкт-Петербург, 2003.

Кульчицький С. Російська революція 1917 року: новий погляд. Київ, 2008.

Ленин В. I. Повне зібрання творів. Т. 5. Київ, 1969.

Ленін В. I. Повне зібрання творів. Т. 23. Київ, 1972.

Ленин В. I. Повне зібрання творів. Т. 41. Київ, 1974.

Ленін В. I. Повне зібрання творів. Т. 42. Київ, 1974.

Ленин В. И. Избранные сочинения. Т. 3. Москва, 1984.

Малявин В. Военный канон Китая. Сунь-цзы. Сунь Бинь. Москва, 2016.

Марксизм-ленинизм // Прохоров А. М. (Гл. ред.). Большая Советская

Энциклопедия. Т. 15. Москва, 1974.

Сунь-Цзи. Мистецтво війни. Харків, 2016.

Hoffman F. G. Hybrid Warfare and Challenges. URL: https://smallwarsjournal. com/documents/jfqhoffman.pdf

\section{REFERENCES}

Horbulin V. (2016), Hibrydna vijna: vse til'ky pochynaiet'sia, Dzerkalo tyzhnia, available at: https://dt.ua/internal/gibridna-viyna-vse-tilki-pochinayetsya-_html (accessed 7 October 2020). (In Ukrainian).

Horbulin, V. (Ed.) (2017) Svitova hibrydna vijna: ukrains'kyj front. Kharkiv: Folio. (In Ukrainian).

Klauzevic, K. fon (2002). O vojne : v 2 t. Moscow: OOO «Izdatel'stvo AST». (In Russian).

Konrad N. I. (1977). Izbrannye trudy: Sinologiya. Moscow: Glavnaya redakciya vostochnoj literatury. (In Russian).

Konrad N. I. (Ed.) (2003) Traktaty o voennom iskusstve. Sun'-Czy, U-Czy. Moscow: OOO «Izdatel'stvo AST», SPb.: Terra Fantastica. (In Russian).

Kul'chyts'kyj, S. (2008). Rosijs 'ka revoliutsiia 1917 roku: novyj pohliad. Kyiv: Nash chas. (In Ukrainian).

Lenyn, V. I. (1969). Povne zibrannia tvoriv. Vol. 5. Kyiv: Vydavnytstvo politychnoi literatury Ukrainy. (In Ukrainian).

Lenyn, V. I. (1972). Povne zibrannia tvoriv. Vol. 23. Kyiv: Vydannytstvo politychnoi literatury Ukrainy. (In Ukrainian).

Lenyn, V. I. (1974). Povne zibrannia tvoriv. Vol. 41. Kyiv: Vydavnytstvo politychnoi literatury Ukrainy. (In Ukrainian).

Lenyn, V. I. (1974). Povne zibrannia tvoriv. Vol. 42. Kyiv: Vydavnytstvo politychnoi literatury Ukrainy. (In Ukrainian). 
Lenin V. I. (1984). Izbrannye sochineniya. Vol. 3. 1901-1904. Moscow: Izdatel'stvo politicheskoj literatury. (In Ukrainian).

Marksizm-leninizm In Proxorov, A. M. (Ed.) (1974). Bol'shaya Sovetskaya E'nciklopediya. Vol. 15. Moscow: Iz-vo "Sovetskaya e'nciklopediya". (In Russian).

Malyavin V. (Ed.) (2016). Voennyj kanon Kitaya. Sun'-czy. Sun'Bin'. Moscow: Ripol-klassik. (In Russian).

Sun'-Tszy. (2016). Mystetstvo vijny. Kharkiv: Klub simejnoho dozvillia. (In Ukrainian).

Hoffman, F. G. (n. d.) Hybrid Warfare and Challenges. Small Wars Journals. Available at: https://smallwarsjournal.com/documents/jfqhoffman.pdf. (In English).

\section{ДАОСИЗМ І МАРКСИЗМ-ЛЕНІНІЗМ: ПОСДНУЮЧИ НЕПОСДНУВАЛЬНЕ. ЩОДО ДОЦІЛЬНОСТІ ВИВЧЕННЯ КЛАСИКІВ У ДОСЛІДЖЕННІ МЕТОДОЛОГІЇ ВЕДЕННЯ СУЧАСНОЇ ГІБРИДНОЇ ВІЙНИ}

\section{М. С. Кучерук}

У вивченні гібридних воєн і виробленні успішних протидій гібридним загрозам, на нашу думку, надзвичайно велику вагу має досвід стародавнього Китаю. Там із давніх часів існує воєнна доктрина - витончене мистецтво досягати своїх цілей. Ця військова наука трималася в секреті й маловідома навіть у самому Китаї. Ми маємо дякувати синологам, які відкрили нам таємничий світ Азії, не тільки переклали твори китайських класиків, а й забезпечили нас коментарями й дослідженнями, що дають можливість не тільки читати твори стародавніх стратегів, а й розуміти їх.

Щодо дослідження методів гібридної війни, застосованих В. Леніним, і пошуків історичних прецедентів уважаємо більш доцільним опиратися на доктрину Сунь-цзи. Немає відомостей, чи вивчав Ленін трактат «Мистецтво війни», але на практиці він використав усі його настанови. Наприклад, «Майстерний лідер прищеплює норми моралі й суворо дотримується методу та дисципліни; тому й важить головою за успіх», «Війна - це шлях обману» тощо.

Досвід більшовиків демонструє, що головним у їхній стратегії стало завоювання умів, панування над свідомістю мас, а конкретні практичні кроки стали вже другорядними й похідними. В. Ленін, зокрема, мав звичку починати полеміку зі своїми опонентами з ідеологічних питань. На відміну від В. Леніна, його противники вважали ідеологічні питання несуттєвими. Друга відмінність ленінської методології - ії еклектичний характер. Пишучи про необхідність творчого застосування теорії К. Маркса й застерігаючи від догматичного сприйняття марксизму, В. Ленін говорив про застосування різних форм і методів «революційної боротьби» й швидкої заміни однієї форми боротьби іншою за необхідності (див. «Дитяча «хвороба лівизни» в комунізмі»).

Отже, сучасна гібридна війна також, по суті, $є$ еклектикою, що поєднує в собі різноманітні форми й засоби, навіть далекі від традиційної війни. У цьому сенсі вона відповідає духу нашого часу - глобалізації, що вбирає всі культури світу. Також глобалізація зробила світ видимим, а методи ведення війн не нові, лише модернізовані рецепти класиків. Придворні інтриги і стратагеми давно вийшли за межі палаців, тепер вони охоплюють усіх, а не лише аристократію.

Ключові слова: гібридна війна, В. Ленін, Сунь-цзи, дао, організація, пропаганда, ідеологія.

\section{ДАОСИЗМ И МАРКСИЗМ-ЛЕНИНИЗМ: СОЧЕТАЯ НЕСОЧЕТАЕМОЕ. О ЦЕЛЕСООБРАЗНОСТИ ИЗУЧЕНИЯ КЛАССИКОВ В ИССЛЕДОВАНИИ МЕТОДОЛОГИИ ВЕДЕНИЯ СОВРЕМЕННОЙ ГИБРИДНОЙ ВОЙНЫ}

\section{М. С. Кучерук}

В изучении гибридных войн и выработке успешного противодействия гибридным угрозам полагаем, что весьма большой вес имеет опыт древнего Китая. Там с древних времен существует военная доктрина - изящное искусство достигать своих целей. 
Эта военная наука держалась в секрете и малоизвестная даже в самом Китае. Мы должны благодарить синологов, которые открыли нам таинственный мир Азии, не только перевели произведения китайских классиков, но и обеспечили нас комментариями и исследованиями, которые дают возможность не только читать произведения древних стратегов, но и понимать их.

В исследовании методов гибридной войны, примененных В. Лениным, и в поисках исторических прецедентов считаем более целесообразным опираться на доктрину Сунь-цзы. Нет сведений, изучал ли В. Ленин трактат «Искусство войны», но на практике он использовал все его наставления. К примеру, «Искусный лидер прививает нормы морали и строго придерживается метода и дисциплины; поэтому и отвечает головой за успех», «Война - это путь обмана» и другие.

Опыт большевиков демонстрирует, что главным в их стратегии стало завоевание умов, господство над сознанием масс, а конкретные практические шаги стали уже второстепенными и производными. Ленин, в частности, всегда начинал полемику со своими оппонентами с идеологических вопросов. В отличие от В. Ленина, его противники считали идеологические вопросы несущественными. Второе отличие ленинской методологии - ее эклектичный характер. В. Ленин также писал о необходимости творческого применения теории К. Маркса, предостерегая от догматического восприятия марксизма, Ленин говорил о применении различных форм и методов «революционной борьбы» и быстрой замене одной формы борьбы другой при необходимости (см. «Детская «болезнь левизны» в коммунизме»).

Следовательно, современная гибридная война также, по сути, является эклектикой, сочетающей различные формы и средства, даже далекие от традиционной войны. В этом смысле она соответствует духу нашего времени - глобализации, вбирает в себя все культуры мира. Также глобализация сделала мир видимым, а методы ведения войн не новы, только модернизированные рецепты классиков. Придворные интриги и стратагемы вышли давно за пределы дворцов, теперь они охватывают всех, а не только аристократию.

Ключевые слова: гибридная война, Ленин, Сунь-цзы, дао, организация, пропаганда, идеология. 